\title{
SUBYEK HAK MILIK ATAS TANAH MENURUT UUPA
}

\author{
Bambang Sudiarto ${ }^{1}$ \\ bambangsudiarto25@gmail.com \\ Fakultas Hukum Universitas Muhammadiyah Jakarta \\ Jl. KH. Ahmad Dahlan, Cirendeu, Ciputat, Tangerang Selatan, Banten.
}

\begin{abstract}
Abstrak
Sejak diundangkan dan diberlakukan UUPA pada tahun 1960, di dalam pertanahan berlaku kaiadah-kaidah hukium ditetapkan di dalamnya. Di antaranya kaidah-kaidah hukum dalam Pasal 21 UUPA, mengamanatkan (1) hanya warga negara Indonesia dapat mempunyai hak milik. (2) oleh Pemerintah ditetapkan badan-badan hukum yang dapat mempunyai hak milik dan syarat-syaratnya. Tampak jelas dalam kaidah-kaidah hukum pasal di atas, diketahui berdasarkan kaidah hukum dalam UUPA yang dapat mempunyai hak milik atas tanah hanya Warganegara Indonesia saja. Meski begitu UUPA memberi kewenangan kepada Pemerintah untuk menetapkan badan-badan- hukum yang dapat memiliki hak milik atas tanah, terbatas pada badan-badan hukum dengan bidang usah'a sosial dan keagamaan.
\end{abstract}

Kata Kunci: Subyek, Hak Milik Atas Tanah, dan UU Pokok Agraria

\section{Abstract}

Since the promulgation and enactment of the UUPA in 1960, in the land area, the legal rules stipulated in it have been applied. Among them are the legal rules in Article 21 of the UUPA, which mandates (1) only Indonesian citizens can have property rights. (2) The Government shall determine legal entities that can have

${ }^{1}$ Dosen Tetap Fakultas Hukum Universitas Muhammadiyah Jakarta 


\section{AL-QISTH LAW REVIEW \\ VOL 5 NO. 1 (2021)}

property rights and the conditions thereof. It is clear in the legal rules of the article above, it is known that based on the legal rules in the UUPA, only Indonesian citizens can have ownership rights over land. Even so, the UUPA gives the Government the authority to determine legal entities that can have ownership rights over land, limited to legal entities with social and religious business sectors.

Keywords: Subjects, Property Rights on Land, and Basic.

\section{A. PENDAHULUAN}

\section{a. Latar Belakang Masalah}

Sejak Undang-undang Republik Indonesia Nomor 5 Tahun 1960 tentang Peraturan Dasar Pokok-pokok Agraria, disahkan dan diundangkan pada tanggal 24 Tahun 1960, oleh Presiden Republik Indonesia Soekarno dan oleh Sekretaris Negara Tamzil, dimuat dalam Lembaran Negara tahun 1960 Nomor 104, dimuat dalam Lembaran Tambahan Negara tahun 1960 Nomor 2043, (untuk selanjutnya ditulis dan dibaca UUPA), dalam bidang pertanahan atau agraria, mengalami dan terjadinya perubahan. Perubahan yang terjadi sebagai akibat dari diundangkannya UUPA, kaidah-kaidah hukum yang ditetapkan dan diatur dalam peraturan-peraturan yang memuat bidang pertanahan atau agraria menjadi tidak berlaku, sebagaimana dinyatakan dalam konsideran memutusnya, dengan mencabut:

1. "Agrarische Wet" (Staatsblad 1870 No. 55) sebagai yang termuat dalam pasal 51 "Wet op de Staatsinrichting van 


\section{AL-QISTH LAW REVIEW \\ VOL 5 NO. 1 (2021)}

Nederlands Indie" (Staatsblad 1925 No. 447) dan ketentuan dalam ayat-ayat lainnya dari pasal itu;

2. a. "Domeinverklaring" tersebut dalam pasal 1 "Agrarisch Besluit" (Staatsblad 1870 No. 118);

b. "Algemene Domeinverklaring" tersebut dalam Staatsblad 1875 No. 119A;

c. "Domeinverklaring untuk Sumatera" tersebut dalam pasal 1 dari Staatsblad 1874 No. 94f;

d. "Domeinverklaring untuk keresidenan Menado" tersebut dalam pasal 1 dari Staatsblad 1877 No. 55;

e. "Domeinverklaring untuk residentie Zuider en Oosterafdeling van Borneo" tersebut dalam pasal 1 dari Staatsblad 1888 No. 58;

3. Koninklijk Besluit tanggal 16 April 1872 No. 29 (Staatsblad 1872 No. 117) dan peraturan pelaksanaannya;

4. Buku ke-II Kitab Undang-Undang Hukum Perdata Indonesia sepanjang yang mengenai bumi, air serta kekayaan alam yang terkandung di dalamnya, kecuali ketentuan-ketentuan mengenai hypotheek yang masih berlaku pada mulai berlakunya Undang-undang ini; Merupakan undang-undang yang tidak membedakan antara laki-laki dan perempuan di dalam pemilikan tanah, meskipun di dalam KUH Perdata perempuan masih dianggap tidak cakap untuk melakukan perbuatan hukum secara mandiri. 


\section{4}

\section{AL-QISTH LAW REVIEW \\ VOL 5 NO. 1 (2021)}

Selain itu, dengan disahkan dan diundangkan UUPA, dalam bidang pertanahan berlakulah kaidah-kaidah hukum yang ditetapkan dalam UUPA, menimbulkan akibat hukum sebagai berikut.

1. Mencabut dan mentidakberlakukan kaidah-kaidah hukum pertanahan yang ditetapkan dan diatur dalam kaidah-kaidah hukum peraturan perundang-undangan lain, sebagaimana dinyatakan dalam konsideran UUPA.

2. Mencabut dan mentidakberlakukan kaidah-kaidah hukum tentang tata cara jual beli dan peralihan kepemilikan hak milik atas tanah yang diatur dan ditetapkan dalam Pasal 616 dan Pasal 620 KUH Perdata. Dan sebagai penggantinya berlaku kaidah-kaidah hukum yang ditetapkan dan diatur dalam PP Pendaftaran Tanah.

Dalam tata urut-urutan Peraturan Perundang-undangan yang ditetapkan dan diatur dalam Ketetapan Majelis Permusyawaratan Rakyat Republik Indonesia (TAP MPR RI) Nomor III/MPR RI/2003 tentang Sumber Hukum Dan Tata Urutan Peraturan Perundang-undangan, undang-undang merupakan salah satu bentuk di antara bentuk-bentuk Peraturan Perundang-undangan lainnya. Undang-undang di dalam tata urutan Peraturan Perundang-undangan ditempatkan pada nomor urut 3 (tiga) setelah Undang-Undang Dasar 1945 dan TAP MPR RI. Hal demikian dikarenakan dan terkandung maksud sebagai berikut :

1. Sebagai yang ditetapkan dan diatur dalam Pasal 3 TAP MPR RI Nomor III/MPR RI/2000, menentukan undang-undang dibuat 


\section{5}

\section{AL-QISTH LAW REVIEW \\ VOL 5 NO. 1 (2021)}

oleh Dewan Perwakilan Rakyat bersama Presiden untuk melakasanakan UUD 1945 dan perubahannya serta TAP MPR RI.

2. Untuk itu undang-undang berlaku mengikat terhadap seluruh warganegara Indonesia.

3. Untuk itu undang-undang berlaku mengikat terhadap Peraturan Perundang-undangan dalam bentuk yang lebih rendah.

4. Untuk itu undang-undang baru dapat berlaku secara efektif sebagaimana ditetapkan dan diatur dalam Pasal 3 TAP MPR RI Nomor III/MPR/2000, menetapkan Peraturan Pemerintah dibuat oleh Pemerintah untuk melaksanakan perintah undang-undang. Peraturan Pelaksanaan dari kaidah-kaidah hukum yang ditetapkan dan diatur dalam UUPA untuk bidag pertanahan pada masa sekarang telah diundangkan dan diberlakukan 2 (dua) Peraturan Pemerintah, sebagai berikut :

a) Peraturan Pemerintah Republik Indonesia Nomor 10 Tahun 1961 tentang Pendaftaran Tanah, ditetapkan dan diundangkan pada tanggal yang sama 23 Maret 1961, oleh Presiden Republik Indonesia Soekarno dan Sekretaris Negara Mohd. Ichsan. (untuk selanjutnya ditulis dan dibaca PP Pendaftaran Tanah 1961).

b) Kemudian PP Pendaftaran Tanah 1961 setelah berlaku selama 36 tahun dilakukan perubahan dengan Peraturan Pemerintah Republik Indonesia Nomor 24 Tahun 1997 tentang Pendaftaran Tanah, ditetapkan dan diundangkan 


\section{6}

\section{AL-QISTH LAW REVIEW}

VOL 5 NO. 1 (2021)

pada tanggal yang sama 8 Juli 1997, oleh Presiden Republik Indonesia Soeharto dan diundangkan oleh Menteri Negara Sekretaris Negara Republik Indonesia Moerdiono, dimuat dalam Lembaran Negara Republik Indonesia Nomor 3696, Tambahan Lembaran Negara Republik Indonesia 59, (untuk selanjutnya ditulis dan dibaca PP Pendaftaran Tanah).

Ke 2 (dua) Peraturan Pemerintah Republik Indonesia dalam bidang Pertanahan atau Agraria tersebut, tidak berlaku secara bersamaan, melainkan Peraturan Pemerintah yang satu disahkan dan diundangkan untuk menggantikan Peraturan Pemerintah satunya, yang sudah tidak mendukung pembangunan. Sebagaimana dinyatakan dalam konsideran menimbang PP Pendaftaran Tanah 1997 “bahwa Peraturan Pemerintah Nomor 10 Tahun 1961 tentang Pendaftaran Tanah dipandang tidak dapat lagi sepenuhnya mendukung tercapainya hasil yang lebih nyata pada pembangunan nasional, sehingga perlu dilakukan penyempurnaan". Oleh karenanya hingga tahun 2019 Peraturan Pemerintah Republik Indonesia Nomor 24 tahun 1997 tentang Pendaftaran Tanah, yang merupakan Peraturan Pemerintah yang disahkan dan diundangkan terakhir sebagai Peraturan Pelaksanaan dari UUPA. Sebagai Peraturan Pelaksanaan dari UUPA PP Pendaftaran Tanah tersebut memuat 10 Bab, 66 Pasal, Penjelasan Umum dan Penjelasan Pasal demi pasal.

UUPA memuat 5 (lima) buku, 58 (limapuluh delapan) Pasal, 9 (sembilan) Pasal Rumawi 12 (duabelas) bagian dan 4 (empat) Bab. Perihal 


\section{7}

\section{AL-QISTH LAW REVIEW \\ VOL 5 NO. 1 (2021)}

hak milik diatur dalam Bab II tentang hak-hak atas tanah Tanah, Air dan Ruang Angkasa serta Pendaftaran Tanah, bagian I sampai dengan Bagian XII, mulai Pasal 16 sampai dengan Pasal 51 UUPA. Dan kaidah-kaidah hukum hak milik ditetapkan dan diatur dalam Bagian III mulai Pasal 20 sampai dengan Pasal 27 UUPA, sekitar 8 (delapan) pasal.

Tampak jelas dapat dibaca dan diketahui dari kaidah hukum yang ditetapkan dan diatur dalam Bab II UUPA mengatur perihal hak-hak atas tanah Tanah, Air dan Ruang Angkasa serta Pendaftaran Tanah. Oleh karena itu di dalam pasal-pasal yang memuat dan mengatur mengenai kaidah-kaidah hukum hak-hak atas tanah tidak ditulis kembali kata atas tanah. Melainkan cukup ditulis kata hak-hak yang dapat dibebankan di atas tanahnya saja, seperti di antaranya kaidah hukum yang menetapkan dan menentukan rumusan hak milik yang dibebankan di atas tanah dimuat dalam Pasal 20 UUPA, hanya ditulis dengan hak milik saja. Sedangkan atas tanahnya tidak dituliskan lagi setelah kata hak-hak. Meskipun demikian dikarenakan UUPA merupakan undang-undang yang di antaranya menetapkan dan memuat kaidah-kaidah hukum, salah satu di antaranya tentang tanah, maka meski kata atas tanah tidak dituliskan setelah kata hak-hak tetap dianggap dituliskan, sebagai meski tertulis kata hak milik saja, sudah dimaksudkan sebagai hak milik atas tanah.

Di dalam ilmu hukum penulisan kata hak selalu ditempatkan berpasangan dan bersandingan dengan kata kewajiban. Selain itu 


\section{8}

\section{AL-QISTH LAW REVIEW \\ VOL 5 NO. 1 (2021)}

penulisan kata hak selalu ditempatkan berpasangan dan bersandingan dengan kata milik yang dibebankan dan dilekatkan di atas benda, benda berwujud, baik dalam katagori benda bergerak maupun benda tidak bergerak tidak terkecuali dengan tanah yang di dalam hukum dimasukan ke dalam katagori benda tidak bergerak. Maupun benda tidak berwujud.

Hak yang dibebankan dan dilekatkan pada benda-benda dikenal dengan sebutan hak kebendaan. Sedangkan hak yang dimiliki dan melekat pada diri orang dikenal dengan sebutan hak perorangan. Dengan demikian dapat diketahui baik hak kebendaan maupun hak perorangan selalu berikatan dan berkaitan dengan orang.

Di dalam hukum orang di dalam hukum ditempatkan pada kedudukan selaku subyek hukum dimengerti apabila kaidah-kaidah hukum yang memuat dan mengatur tentang hak dimasukan ke dalam lingkup hukum pribadi (Persoonlijkrecht) dikenal juga dengan sebutan hukum privat (Hukum Perdata). Sebagaimana diketahui hukum perdata merupakan hukum yang mengatur orang, hubungan antar orang dan akibat yang ditimbulkan dari hubungan antar orang baik terhadap para pihak yang melakukan perbuatan menimbulkan akibat hukum berupa hubungan hukum dalam bentuk perikatan. Kaidah-kaidah hukum perdata yang ditetapkan dan mengatur perihal orang dan hak serta kewajiban sebagai subyek hukum, perbuatan hukum dan hubungan hukum antar orang selaku subyek hukum, benda sebagai obyek hukum, termasuk hak kebendaan, hak perorangan dan Pembuktian dan daluwarsa dimuat 


\section{9}

\section{AL-QISTH LAW REVIEW \\ VOL 5 NO. 1 (2021)}

dalam KUH Perdata. Hal demikian disebabkan baik hak kebendaan maupun hak perorangan akan selalu berikatan dan berkaitan dengan orang.

Sebagaimana yang diketahui di dalam Hukum Perdata, mengenai hak dibedakan ke dalam 2 (dua) macam, sebagai berikut.

1. Zakelijke rechten (hak atas benda) adalah hak atas benda yang bersifat zakelijke artinya berlaku terhadap tiap orang. Jadi merupakan hak mutlak atau absolut.

2. Persoonlijke rechten (hak perorangan) adalah hak atas sesuatu obyek (benda) yang hanya berlaku terhadap sesuatu orang lain tertentu. Jadi merupakan hak relatif (Wignjodipoero, 1995).

Perihal pembagian hak dalam hukum perdata, Penulis lain mengemukakan pendapatnya hak dalam hukum perdata dikenal hak perdata bersifat absolut, meliputi :

1. Hak kebendaan (Zakelijkrecht), diatur dalam buku II KUH Perdata.

2. Hak kepribadian (Persoonlijkheidsrecht), yang terdiri dari :

a. Hak atas dari sendiri, misalnya hak atas nama, hak atas kehormatan, hak untuk memiliki, hak untuk kawin.

b. Hak atas dari orang lain, yang tmbul dalam hubungan hukum keluarga antar suami dan istri, antar orang tua dan anak, antar wali dan anak.

Semua hak kepribadian diatur dalam Buku I KUH Perdata, sedangkan Hak Perdata yang bersifat relatif ialah hak yang timbul karena 


\section{AL-QISTH LAW REVIEW \\ VOL 5 NO. 1 (2021)}

adanya hubungan hukum berdasarkan perjanjian atau berdasarkan ketentuan undang-undang, disebut dengan Persoonlijkrecht pada umumnya diatur dalam Buku III KUH Perdata. Dikatakan relatif karena hak ini hanya dapat ditujukan dan dipertahankan terhada pihak dalam hubungan hukum (Muhammad, 2000).

Pemilik hak yang dibebankan di atas atau hak atas benda atau hak kebendaan disebut dengan subyek hak. Sedangkan hak yang dibebankan dan melekat pada diri seseorang yang penulisan dan penempatannya selalu disandingkan dengan kewajiban dan timbulnya karena kedudukan orang yang ditempatkan selaku subyek hukum, sering dikenal dengan sebutan hak perorangan.

Kata atas tanah dikandung maksud di atas tanah, tidak diartikan dengan ditancapkan, ditanam, ditaruh di hamparan tanah yang bersangkutan, sebagaimana pada umumnya yang terjadi pada bendabenda yang ditancapkan dan diletakan di atas tanah, pohon dan tanaman ditanam di atas tanah. Hal demikian dikarenakan hak tidak terlihat dan tidak dapat diraba, melainkan hanya dapat dirasakan kemelekatannya ketika diberikan oleh pihak lain dengan melaksanakan kewajiban yang dibebankan kepada dirinya. Sehingga hak atas tanah merupakan hak yang melekat pada tanah yang dibebani dengan hak di atasnya, baik yang bersifat sementara, berbatas waktu maupun untuk selama tanah yang dibebani dengan hak yang bersangkutan belum musnah atau masih ada, sebagaimana yang ditetapkan di dalam Pasal 16 UUPA. 


\section{1}

\section{AL-QISTH LAW REVIEW \\ VOL 5 NO. 1 (2021)}

Hak atas tanah termasuk ke dalam katagori hak kebendaan yang tidak berbeda dengan hak kebendaan-hak kebendaan lainnya yg dapat dibebankan di atas benda-benda lainnya sebagai obyek hukum. Hak kebendaan dapat dihaki oleh orang selaku subyek hukum, pemegang hak kebendaan dikenal dengan subyek hak kebendaan.

Perihal hak milik atas tanah ditetapkan, diatur dan dimuat mulai Pasal 20 UUPA sampai dengan Pasal 27 UUPA, seluruhnya sejumlah 8 pasal. Di antara pasal-pasal tersebut, kaidah-kaidah hukum yang memuat rumusan arti hak milik ditetapkan dan dimuat dalam Pasal 20 UUPA, menentukan :

(1) Hak milik adalah hak turun-menurun, terkuat dan terpenuh yang dapat dipunyai orang atas tanah, dengan mengingat ketentuan dalam pasal 6.

(2) Hak milik dapat beralih dan dialihkan kepada pihak lain.

Kemudian rumusan kaidah hukum yang ditetapkan dan diatur dalam Pasal 21 UUPA menetapkan :

(1) Hanya warga-negara Indonesia dapat mempunyai hak milik.

(2) Oleh Pemerintah ditetapkan badan-badan hukum yang dapat mempunyai hak milik dan syarat-syaratnya.

(3) Orang asing yang sesudah berlakunya Undang-undang ini memperoleh hak milik karena pewarisan tanpa wasiat atau percampuran harta karena perkawinan, demikian pula warga-negara Indonesia yang mempunyai hak milik dan setelah berlakunya Undang-undang ini kehilangan kewarga-negaraannya wajib melepaskan hak itu didalam jangka waktu 


\section{AL-QISTH LAW REVIEW \\ VOL 5 NO. 1 (2021)}

satu tahun sejak diperolehnya hak tersebut atau hilangnya kewarganegaraan itu. Jika sesudah jangka waktu tersebut lampau hak milik itu dilepaskan, maka hak tersebut hapus karena hukum dan tanahnya jatuh pada Negara, dengan ketentuan bahwa hak-hak pihak lain yang membebaninya tetap berlangsung.

(4) Selama seseorang disamping kewarganegaraan Indonesianya mempunyai kewarga-negaraan asing maka ia tidak dapat mempunyai tanah dengan hak milik dan baginya berlaku ketentuan dalam ayat (3) pasal ini.

Merujuk pada uraian rumusan bunyi pasal di atas, dapat diketahui dan dikemukakan, "hak milik atas tanah merupakan hak atas kebendaan adalah hak mutlak atas suatu benda, dimana hak itu memberikan kekuasaan langsung atas suatu benda dan dapat dipertahankan terhadap siapapun juga" (Meliala, 2012).

Selain itu dapat diketahui dan dikemukakan pula subyek atau pemilik hak milik atas tanah menurut Pasal 21 UUPA yang dapat mempunyai hak milik adalah hanya Warganegara Indonesia dan oleh Pemerintah ditetapkan badan-badan hukum yang dapat mempunyai hak milik dan syarat-syaratnya. Kaidah-kaidah hukum yang ditetapkan dan diatur dalam pasal tersebut jika dibaca secara sepintas tampak jelas, tidak demikian halnya jika dibaca secara perlahan kemudian ditelaah secara seksama akan ditemukan pengertian yang menimbulkan persepsi yang tidak searah dengan rumusan bunyi pasal tersebut. Untuk itu cukup menarik untuk dilakukan penulisan mengenai subyek hak milik atas tanah menurut UUPA. 


\section{AL-QISTH LAW REVIEW \\ VOL 5 NO. 1 (2021)}

\section{b. Rumusan Masalah.}

Mendasarkan pada latar belakang masalah yang diuraikan di atas, dapat dirumuskan masalah dalam penulisan ini, sebagai berikut :

1. Siapa-siapa yang dapat menjadi subyek hak milik atas tanah menurut UUPA ?

2. Siapa yang disebut dengan Warganegara Indonesia yang boleh memiliki hak milik atas tanah?

\section{B. PEMBAHASAN.}

Dalam Kamus Besar Bahasa Indonesia subyek diartikan dengan beragam 1 pokok pembicaraan; pokok bahasan; “2 Ling bagian klausa yang menandai apa yang dikatakan oleh pembicara; pokok kalimat; 3 pelaku: dalam pengkajian itu manusia dapat berperan sebagai - di samping sebagai objek pengkajian; 4 mata pelajaran: bahasa Indonesia merupakan - pokok di sekolah; 5 orang, tempat, atau benda yang diamati dalam rangka pembuntutan sebagai sasaran". Kata subyek dalam kamus Besar Bahasa Indonesia, hanya dirumuskan dengan arti "subjek" (Depdikbud, 1995).

Sedangkan dalam Kamus Hukum kata subyek dirumuskan dengan arti "pokok, pelaku, pihak". Selain itu kata subyek diartikan pula dengan: "1. Pokok Pembicaraan, Pokok Bahasan; 2. Bagian klausa yang menendai apa yang dikatakan oleh pembicara; Pokok Kalimat; 3. Pelaku; 4. Mata pelajaran; 5. Orang, tempat, atau benda yang diamati dalam rangka pembuntutan sebagai 


\section{AL-QISTH LAW REVIEW \\ VOL 5 NO. 1 (2021)}

sasaran". Dalam penjelasan Umum II angka (1) UUPA menerangkan, Adapun hubungan antara bangsa dan bumi, air serta ruang angkasa tersebut tidak berarti, bahwa hak milik perseorangan atas (sebagian dari) bumi tidak dimungkinkan lagi. Diatas telah dikemukakan, bahwa hubungan itu adalah semacam hubungan hak ulayat, jadi bukan berarti hubungan milik. Dalam rangka hak ulayat dikenal adanya hak milik perseorangan. Kiranya dapat ditegaskan bahwa dalam hukum agraria yang baru dikenal pula hak milik yang dapat dipunyai seseorang, baik sendiri maupun bersama-sama dengan orang-orang lain atas bagian dari bumi Indonesia (pasal 4 yo pasal 20). Dalam pada itu hanya permukaan bumi saja, yaitu yang disebut tanah, yang dapat dihaki oleh seseorang.

Sebagaimana dikemukakan dalam uraian di atas, kaidah-kaidah hukum perihal hak milik atas tanah ditetapkan, diatur dan dimuat dalam mulai Pasal 20 sampai dengan Pasal 27 UUPA, sejumlah 8 pasal. Di antara pasal-pasal tersebut salah satunya memuat kaidah-kaidah hukum tentang kepemilikan hak milik seperti yang ditetapkan dalam Pasal 21 UUPA menentukan:

(1) Hanya warga-negara Indonesia dapat mempunyai hak milik.

(2) Oleh Pemerintah ditetapkan badan-badan hukum yang dapat mempunyai hak milik dan syarat-syaratnya.

(3) Orang asing yang sesudah berlakunya Undang-undang ini memperoleh hak milik karena pewarisan tanpa wasiat atau percampuran harta karena perkawinan, demikian pula warga-negara Indonesia yang mempunyai hak milik dan setelah berlakunya Undang-undang ini kehilangan kewarga- 


\section{5}

\section{AL-QISTH LAW REVIEW \\ VOL 5 NO. 1 (2021)}

negaraannya wajib melepaskan hak itu didalam jangka waktu satu tahun sejak diperolehnya hak tersebut atau hilangnya kewarga-negaraan itu. Jika sesudah jangka waktu tersebut lampau hak milik itu dilepaskan, maka hak tersebut hapus karena hukum dan tanahnya jatuh pada Negara, dengan ketentuan bahwa hak-hak pihak lain yang membebaninya tetap berlangsung.

(4) Selama seseorang disamping kewarga-negaraan Indonesianya mempunyai kewarga-negaraan asing maka ia tidak dapat mempunyai tanah dengan hak milik dan baginya berlaku ketentuan dalam ayat (3) pasal ini.

Tampak jelas dapat dibaca kaidah-kaidah hukum dalam Pasal 21 UUPA tersebut, telah menetapkan yang dapat memiliki hak milik atas tanah, dengan membedakan ke dalam 2 (dua) kelompok, sebagai berikut:

\section{a. Ditetapkan Dalam Undang-Undang.}

Kaidah-kaidah hukum yang diatur dalam Pasal 21 ayat 1 UUPA telah menetapkan dengan tegas "hanya Warganegara Indonesia dapat mempunyai hak milik. Penjelasan II angka 5 UUPA menyatakan sesuai dengan azas kebangsaan tersebut dalam Pasal 1 maka menurut Pasal 9 yo Pasal 21 ayat 1 hanya Warganegara Indonesia saja yang dapat mempunyai hak milik atas tanah".

Mengacu pada uraian di atas, dapat diketahui penetapan kaidah hukum "hanya warganegara Indonesia yang dapat mempunyai hak milik atas tanah" dalam pasal di atas, penetapan dan penempatannya tidak dilakukan secara tiba-tiba dan mendadak, melainkan memiliki keterikatan dan keterkaitan dengan kaidah-kaidah hukum yang dikenal dengan 


\section{AL-QISTH LAW REVIEW}

VOL 5 NO. 1 (2021)

sebutan asas kebangsaan yang ditetapkan dalam pasal-pasal, sebagai berikut :

1. Alinea I Pembukaan UUD NRI Tahun 1945 menyatakan bahwa sesungguhnya kemerdekaan itu ialah hak segala bangsa dan oleh sebab itu, maka penjajahan di atas dunia harus dihapuskan, karena tidak sesuai dengan peri-kemanusiaan dan peri-keadilan.

2. Alinea IV Pembukaan UUD NRI Tahun 1945 menyatakan kemudian daripada itu untuk membentuk suatu Pemerintah Negara Indonesia yang melindungi segenap bangsa Indonesia dan seluruh tumpah darah Indonesia dan untuk memajukan kesejahteraan umum, mencerdaskan kehidupan bangsa, dan ikut melaksanakan ketertiban dunia yang berdasarkan kemerdekaan, perdamaian abadi dan keadilan sosial, maka disusunlah Kemerdekaan Kebangsaan Indonesia itu dalam suatu Undang-undang Dasar Negara Indonesia, yang terbentuk dalam suatu susunan Negara Republik Indonesia yang berkedaulatan rakyat dengan berdasar kepada : Ketuhanan Yang Maha Esa, Kemanusiaan yang adil dan beradab, Persatuan Indonesia, dan Kerakyatan jang dipimpin oleh hikmat kebijaksanaan dalam permusyawaratan/perwakilan, serta dengan mewujudkan suatu Keadilan sosial bagi seluruh rakyat Indonesia.

3. Pasal 33 ayat (3) UUD NRI Tahun 1945 menyatakan bumi dan air dan kekayaan alam yang terkandung di dalamnya dikuasai oleh Negara dan dipergunakan untuk sebesar-besar kemakmuran rakyat.

4. Pasal 1 UUPA menetapkan:

(1) Seluruh wilayah Indonesia adalah kesatuan tanah-air dari seluruh rakyat Indonesia yang bersatu sebagai bangsa Indonesia. 


\section{AL-QISTH LAW REVIEW \\ VOL 5 NO. 1 (2021)}

(2) Seluruh bumi, air dan ruang angkasa, termasuk kekayaan alam yang terkandung didalamnya dalam wilayah Republik Indonesia, sebagai karunia Tuhan Yang Maha Esa adalah bumi, air dan ruang angkasa bangsa Indonesia dan merupakan kekayaan nasional.

(3) Hubungan antara bangsa Indonesia dan bumi, air serta ruang angkasa termaksud dalam ayat (2) pasal ini adalah hubungan yang bersifat abadi.

(4) Pengertian bumi, selain permukaan bumi, termasuk pula tubuh bumi dibawahnya serta yang berada dibawah air.

(5) Dalam pengertian air termasuk baik perairan pedalaman maupun laut wilayah Indonesia.

(6) Yang dimaksud dengan ruang angkasa ialah ruang diatas bumi dan air tersebut pada ayat (4) dan (5) pasal ini.

5. Pasal 9 UUPA, menentukan:

(1) Hanya Warganegara Indonesia dapat mempunyai hubungan yang sepenuhnya dengan bumi, air dan ruang angkasa, dalam batas-batas ketentuan pasal 1 dan 2.

(2) Tiap-tiap Warganegara Indonesia, baik laki-laki maupun wanita mempunyai kesempatan yang sama untuk memperoleh sesuatu hak atas tanah serta untuk mendapat manfaat dari hasilnya, baik bagi diri sendiri maupun keluarganya.

Merujuk pada rumusan bunyi pasal-pasal di atas, dapat dikemukakan perihal yang dapat memiliki (subyek) hak milik atas tanah UUPA, sebagai berikut: 


\section{AL-QISTH LAW REVIEW \\ VOL 5 NO. 1 (2021)}

1. UUPA hanya membedakan Warganegara Indonesia dengan Warganegara Asing.

2. UUPA tidak membedakan laki-laki dan wanita, melainkan menempatkan pada kedudukan yang sama, sama-sama boleh memiliki atau menjadi subyek hak milik atas tanah.

3. UUPA tidak mengenal pembagian golongan penduduk yang diatur dalam Pasal 163 ayat (1) I.S. menyatakan "jikalau ketentuanketentuan dalam undang-undang ini, dalam peraturan umum dan peraturan setempat, dalam aturan-aturan, peraturan polisi dan administrasi diadakan perbedaan antara golongan Eropah, Pribumi dan Timur Asing"' (Kartohadiprodjo, 1981).

Tampak dalam ketentuan-ketentuan dalam Pasal 163 I.S. dinyatakan dengan jelas diawali dengan kata "jikalau ketentuanketentuan dalam undang-undang ini". Ini menunjukan sebelum pasal tersebut telah ditetapkan dan diatur terlebih dahulu dalam pasal sebelummya Pasal 131 I.S. menyatakan :

(1) Hukum sipil dan hukum dagang, hukum pidana, hukum acara perdata dan hukum acara pidana, diatur dengan Ordonansi atau dikodifisir.

(2) Memberi petunjuk kepada (pembentuk ordonansi) syarat apakah yang harus diperhatikan, jikalau mengadakan ordonansi yang memuat hukum sipil dan hukum dagang (hukum perdata).

(3) Memuat petunjuk-petunjuk mengenai hukum pidana, hukum acara perdata dan pidana. 


\section{AL-QISTH LAW REVIEW \\ VOL 5 NO. 1 (2021)}

(4) Di buka kemungkinan kepada golongan-golongan bukan Eropa menurut ketentuan-ketentuan dalam suatu ordonansi tersendiri untuk tunduk kepada hukum perdata barat.

(5) Tidak berlaku dengan sendiri ordonansi-ordonansi yang dimaksud dalam pasal ini di daerah tertentu.

(6) Yang berlaku sebagai hukum perdata bagi golongan Pribumi dan Timur Asing, selama dan sepanjang apa yang berlaku pada saat berlakunya pasal ini (Pasal 131 I.S.) belum diganti dengan ordonansi yang dimaksudkan dalam ayat 2 b pasal 131 tersebut.

Merujuk pada ketentuan yang ditetapkan dan diatur dalam pasal di atas, dapat diketahui terhadap golongan Eropa, harus diperlakukan perundang-undangan yang ada di negeri Belanda dalam bidang Hukum Perdata dan Hukum Dagang (ayat 2 sub a). ayat ini sering disebut sebagai ayat yang memuat asas konkordansi. Sedangkan ayat $2 \mathrm{sub}$ b menyatakan bagi orang Indonesia asli dan Timur Asing, ketentuan Undang-undang Eropa dalam bidang Hukum Perdata dan Hukum Dagang dapat diperlakukan apabila kebutuhan mereka menghendakinya.

Menurut pasal 163 ayat (2) I.S, yang termasuk golongan Eropa, sebagai berikut :

(1) Semua warga negara Belanda;

(2) Orang Eropa;

(3) Warga negara Jepang;

(4) Orang-orang yang berasal dari negara lain yang hukum kekeluargaannya sama dengan hukum keluarga Belanda, terutama azas monogami. 


\section{AL-QISTH LAW REVIEW \\ VOL 5 NO. 1 (2021)}

(5) Keturunan mereka yang tersebut di atas.

Menurut pasal 163 ayat (2) I.S, yang termasuk golongan Eropa, sebagai berikut :

(1) Orang Indonesia asli;

(2) Mereka yang semula termasuk golongan lain, lalu membaurkan dirinya ke dalam orang Indonesia asli.

Menurut pasal 163 ayat (2) I.S, yang termasuk golongan Timur Asing, sebagai berikut:

(1) Golongan Timur Asing Tionghoa (Cina);

(2) Golongan Timur Asing bukan Tionghoa (Simanjuntak, 1999).

Masyarakat Tionghoa Indonesia, merupakan keturunan orangorang Tionghoa yang hijrah dari Tiongkok secara berkala dan bergelombang sejak ribuan tahun lalu. Cara hidup mereka yang cenderung eksklusif dan sangat kuat mempertahankan tradisi, membuat mereka menjadi kelompok yang eksotis menurut sudut pandang Barat. Imigran Tiongkok datang di Indonesia pertama kali sebelum Belanda datang di Indonesia.Imigran pertama datang dari bagian selatan daratan Tiongkok seperti Hokkien di Propinsi Funan kemudian menetap di Batavia. Imigran lain seperti orang-orang Hakko datang dari Kwantung, orang-orang Punto datang dari Konton, orang-orang Hakko dari Swatau, dan orang Haifoeng atau Hailam dari pulau Hounan.

Masyarakat Tionghoa adalah salah satu golongan penduduk yang menurut pasal 131 IS berlaku hukum perdata (BW). Namun di dalam 


\section{1}

\section{AL-QISTH LAW REVIEW \\ VOL 5 NO. 1 (2021)}

implementasinya tidak semua ketentuan-ketentuan yang diatur dalam kitab Undang-Undang hukum perdata diikuti dan bahkan ada kalanya dikesampingkan, misalnya ketentuan - ketentuan yang berkaitan dengan pewarisan sebagaimana diatur didalam Buku II Kitab Undang-Undang Hukum Perdata.

Kaidah-kaidah hukum yang memuat perihal yang dapat mempunyai hak milik atas tanah yang ditetapkan dalam Pasal 21 UUPA dengan tidak membedakan golongan penduduk searah dengan kaidahkaidah hukum yang ditetapkan dalam Undang-undang Republik Indonesia Nomor 62 Tahun 1958 tentang Kewarganegaraan Republik Indonesia, disahkan pada tanggal 29 Juli 1958 oleh Presiden Republik Indonesia Soekarno, dan diundangkan pada tanggal 1 Agustus 1098 oleh Menteri Kehakiman Republik Indonesia G.A. Maengkom (untuk selanjutnya ditulis dan dibaca UU Kewarganegaraan), menetapkan Warganegaraan Republik Indonesia ialah:

(1) orang-orang yang berdasarkan perundang-undangan dan/atau perjanjian-perjanjian dan/atau peraturan yang berlaku sejak proklamasi 17 Agustus 1945 sudah warganegara Republik Indonesia;

(2) orang yang pada waktu lahirnya mempunyai hubungan hukum kekeluargaan dengan ayahnya, seorang warganegara Republik Indonesia, dengan pengertian bahwa kewarganegaraan Republik Indoaesia tersebut dimulai sejak adanya hubungan hukum kekeluargaan termaksud, dan bahwa hubungan hukum kekeluargaan ini diadakan sebelum orang itu berumur 18 tahun atau sebelum ia kawin pada usia di bawah 18 tahun; 
(3) anak yang lahir dalam 300 hari setelah ayahnya meninggal dunia, apabila ayah itu pada waktu meninggal dunia warganegara Republik Indonesia;

(4) orang yang pada waktu lahirnya ibunya warganegara Republik Indonesia, apabila ia pada waktu itu tidak mempunyai hubungan hukum kekeluargaan dengan ayahnya;

(5) orang yang pada waktu lahirnya ibunya warga negara Republik Indonesia, jika ayahnya tidak mempunyai kewarganegaraan, atau selama tidak diketahui kewarganegaraan ayahnya;

(6) orang yang lahir di dalam wilayah Republik Indonesia selama kedua orang tuanya tidak diketahui;

(7) seorang anak yang diketemukan di dalam wilayah Republik Indonesia selama tidak diketahui kedua orang tuanya;

(8) orang yang lahir di dalam wilayah Republik Indonesia, jika kedua orang tuanya tidak mempunyai kewarganegaraan atau selama kewarganegaraan kedua orang tuanya tidak diketahui;

(9) orang yang lahir di dalam wilayah Republik Indonesia yang pada waktu lahirnya tidak mendapat kewarganegaraan ayah atau ibunya, dan selama ia tidak mendapat kewarganegaraan ayah atau ibunya itu;

(10) orang yang memperoleh kewarganegaraan Republik Indonesia menurut aturan-aturan Undang-undang ini.

Undang-undang tersebut kemudian diubah dengan Undangundang Republik Indonesia Nomor 16 Tahun 2012 tentang Kewarganegaraan Republik Indonesia, disahkan pada tgl 12 Juli 2006 oleh Presiden Republik Indonesia Susilo Bambang Yudhoyono, dan 


\section{AL-QISTH LAW REVIEW \\ VOL 5 NO. 1 (2021)}

diundangkan pada tanggal 1 Agustus 2006 oleh Menteri Hukum dan Hak Asasi Manusia Republik Indonesia Hamid Awaludin (untuk selanjutnya ditulis dan dibaca UU Kewaganegaraan), menentukan :

Warga Negara Indonesia adalah:

(1) setiap orang yang berdasarkan peraturan perundang-undangan dan/atau berdasarkan perjanjian Pemerintah Republik Indonesia dengan negara lain sebelum Undang-Undang ini berlaku sudah menjadi Warga Negara Indonesia;

(2) anak yang lahir dari perkawinan yang sah dari seorang ayah dan ibu Warga Negara Indonesia;

(3) anak yang lahir dari perkawinan yang sah dari seorang ayah Warga Negara Indonesia dan ibu warga negara asing;

(4) anak yang lahir dari perkawinan yang sah dari seorang ayah warga negara asing dan ibu Warga Negara Indonesia;

(5) anak yang lahir dari perkawinan yang sah dari seorang ibu Warga Negara Indonesia, tetapi ayahnya tidak mempunyai kewarganegaraan atau hukum negara asal ayahnya tidak memberikan kewarganegaraan kepada anak tersebut;

(6) anak yang lahir dalam tenggang waktu 300 (tiga ratus) hari setelah ayahnya meninggal dunia dari perkawinan yang sah dan ayahnya Warga Negara Indonesia;

(7) anak yang lahir di luar perkawinan yang sah dari seorang ibu Warga Negara Indonesia;

(8) anak yang lahir di luar perkawinan yang sah dari seorang ibu warga negara asing yang diakui oleh seorang ayah Warga Negara Indonesia 


\section{4}

\section{AL-QISTH LAW REVIEW \\ VOL 5 NO. 1 (2021)}

sebagai anaknya dan pengakuan itu dilakukan sebelum anak tersebut berusia 18 (delapan belas) tahun atau belum kawin;

(9) anak yang lahir di wilayah negara Republik Indonesia yang pada waktu lahir tidak jelas status kewarganegaraan ayah dan ibunya;

(10) anak yang baru lahir yang ditemukan di wilayah negara Republik Indonesia selama ayah dan ibunya tidak diketahui;

(11) anak yang lahir di wilayah negara Republik Indonesia apabila ayah dan ibunya tidak mempunyai kewarganegaraan atau tidak diketahui keberadaannya;

(12) anak yang dilahirkan di luar wilayah negara Republik Indonesia dari seorang ayah dan ibu Warga Negara Indonesia yang karena ketentuan dari negara tempat anak tersebut dilahirkan memberikan kewarganegaraan kepada anak yang bersangkutan;

(13) anak dari seorang ayah atau ibu yang telah dikabulkan permohonan kewarganegaraannya, kemudian ayah atau ibunya meninggal dunia sebelum mengucapkan sumpah atau menyatakan janji setia

Merujuk pada rumusan bunyi kaidah-kaidah yang ditetapkan dan diatur dalam pasal-pasal UU Kewarganegaraan di atas, dapat diketahui Negara Kesatuan Republik Indonesia sejak disahkan dan diundangkannya Undang-undang kewarganegaraan tahun 1958, hanya mengenal Warganegara Indonesia dengan tidak membedakan golongan penduduk. Kemudian diperjelas dengan ditetapkannya kaidah-kaidah hukum yang mengatur perihal kepemilikan hak milik atas tanah dalam Pasal 21 UUPA. Berikutnya Presidium Kabinet Ampera telah mengeluarkan Instruksi 


\section{AL-QISTH LAW REVIEW \\ VOL 5 NO. 1 (2021)}

Nomor 31/U/IN/12/1966 kepada Menteri Kehakiman Republik Indonesia dan Kantor-kantor Catatan Sipil (Burgelijke stand) di seluruh Indonesia untuk :

a. Mulai tanggal 27 Desember 1966, tidak menggunakan penggolongan-penggolongan penduduk Indonesia berdasarkan Pasal 131 I.S. (Eropeanen, Vreemde Oostelingen, Inlanders) pada Kantor-kantor Catatan sipil di seluruh Indonesia.

b. Untuk selanjutnya Kantor-kantor Catatan sipil di seluruh Indonesia terbuka bagi penduduk seluruh Indonesia dan orang asing (Thalin, 1987).

Mengacu pada uraian di atas, dapat dikemukakan Negara Kesatuan Republik Indonesia sejak Undang-undang Kewarganegaraan Republik Indonesia 62 Tahun 1958 sudah tidak menggolongkan penduduknya lagi, melainkan membedakan ke dalam Warganegara Indobesia dan Warganegara Asing.

\section{b. Penetapan Pemerintah.}

Sebagaimana telah ditetapkan dalam kaidah-kaidah hukum Pasal 21 UUPA yang mengatur perihal kepemilikan hak milik atas tanah di atas, dengan jelas dan tegas menentukan pihak-pihak yang dapat memiliki hak milik atas tanah dibedakan ke dalam 2 (dua) macam, sebagai berikut :

1. Ditetapkan dan dinyatakan dengan jelas dan tegas dalam kaidahkaidah hukum yang diatur dalam pasal tersebut hanya 


\section{AL-QISTH LAW REVIEW \\ VOL 5 NO. 1 (2021)}

Warganegara Indonesia yang dapat memiliki hak milik atas tanah, dan;

2. Ditetapkan dalam kaidah-kaidah hukum yang diatur dalam pasal tersebut, dinyatakan dengan jelas dan tegas mengamanatkan kepada Pemerintah selaku pemilik hak menguasai Negara untuk menetapkan badan-badan hukum yang dapat mempunyai hak milik atas tanah.

Kaidah-kaidah hukum yang ditetapkan dalam Pasal 21 UUPA bukan kaidah-kaidah hukum yang timbul dan ditetapkan secara tiba-tiba dan tidak memiliki keterikatan dan keterkaitan dengan kaidah-kaidah hukum yang telah ditetapkan dan diatur dalam pasal-pasal sebelumnya, melainkan sebagai pelaksakanaan dari amanat kaidah-kaidah hukum yang telah ditetapkan dan diatur dalam pasal-pasal sebelumnya di antaranya, sebagai berikut:

1. Pasal 1 UUPA menetapkan :

(1) Seluruh wilayah Indonesia adalah kesatuan tanah air dari seluruh rakyat Indonesia yang bersatu sebagai bangsa Indonesia.

(2) Seluruh bumi, air dan ruang angkasa, termasuk kekayaan alam yang terkandung didalamnya dalam wilayah Republik Indonesia, sebagai karunia Tuhan Yang Maha Esa adalah bumi, air dan ruang angkasa bangsa Indonesia dan merupakan kekayaan nasional

(3) Hubungan antara bangsa Indonesia dan bumi, air serta ruang angkasa termaksud dalam ayat (2) pasal ini adalah hubungan yang bersifat abadi. 


\section{AL-QISTH LAW REVIEW \\ VOL 5 NO. 1 (2021)}

(4) Dalam pengertian bumi, selain permukaan bumi, termasuk pula tubuh bumi dibawahnya serta yang berada dibawah air.

(5) Dalam pengertian air termasuk baik perairan pedalaman maupun laut wilayah Indonesia.

(6) Yang dimaksud dengan ruang angkasa ialah ruang diatas bumi dan air tersebut pada ayat (4) dan (5) pasal ini.

2. Pasal 9 UUPA menetapkan :

(1) Hanya Warganegara Indonesia dapat mempunyai hubungan yang sepenuhnya dengan bumi, air dan ruang angkasa, dalam batas-batas ketentuan pasal 1 dan 2.

(2) Tiap-tiap warga-negara Indonesia, baik laki-laki maupun wanita mempunyai kesempatan yang sama untuk memperoleh sesuatu hak atas tanah serta untuk mendapat manfaat dari hasilnya, baik bagi diri sendiri maupun keluarganya.

Penjelasan Umum II Dasar-dasar dari hukum agraria Nasional (1) Pertama-tama dasar kenasionalan itu diletakan dalam pasal 1 ayat 1, yang menyatakan, bahwa : "Seluruh wilayah Indonesia adalah kesatuan tanah air dari seluruh rakyat Indonesia, yang bersatu sebagai bangsa Indonesia" dan pasal 1 ayat 2 yang berbunyi bahwa : "Seluruh bumi, air dan ruang angkasa, termasuk kekayaan alam yang terkandung didalamnya dalam wilayah Republik Indonesia sebagai karunia Tuhan Yang Maha Esa, adalah bumi, air dan ruang angkasa bangsa Indonesia dan merupakan kekayaan nasional". Ini berarti bahwa bumi, air dan ruang angkasa dalam wilayah Republik Indonesia yang kemerdekaannya diperjuangkan oleh bangsa sebagai keseluruhan, 


\section{8}

\section{AL-QISTH LAW REVIEW \\ VOL 5 NO. 1 (2021)}

menjadi hak pula dari bangsa Indonesia, jadi tidak semata-mata menjadi hak dari para pemiliknya saja. Demikian pula tanah-tanah didaerahdaerah dan pulau-pulau tidaklah samata-mata menjadi hak rakyat asli dari daerah atau pulau yang bersangkutan saja. Dengan pengertian demikian maka hubungan bangsa Indonesia dengan bumi, air dan ruang angkasa Indonesia merupakan semacam hubungan hak ulayat yang diangkat pada tingkatan yang paling atas, yaitu pada tingkatan yang mengenai seluruh wilayah Negara.

Mendasarkan pada rumusan bunyi pasal-pasal dan penjelasan di atas, dapat dikemukakan, sebagai berikut :

1. Bumi, air dan ruang angkasa di seluruh wilayah Negara Kesatuan Republik Indonesia, termasuk kekayaan alam yang terkandung di dalamnya merupakan karunia Tuhan Yang Maha Esa kepada Bangsa Indonesia yang wajib dipelihara dengan baik.

2. Bumi, air dan ruang angkasa di seluruh wilayah Negara Kesatuan Republik Indonesia adalah kesatuan tanah air dari seluruh rakyat Indonesia, yang bersatu sebagai bangsa Indonesia.

3. Bumi, air dan ruang angkasa di seluruh wilayah Negara Kesatuan Republik Indonesia merupakan satu kesatuan yang utuh dari seluruh rakyat Indonesia sebagai kekayaan nasional Bangsa Indonesia.

4. Bumi, air dan ruang angkasa di seluruh wilayah Negara Kesatuan Republik Indonesia memiliki hubungan hukum dan abadi dengan Bangsa Indonesia yang telah memperjuangkan kemerdekaannya. 


\section{AL-QISTH LAW REVIEW \\ VOL 5 NO. 1 (2021)}

Meskipun demikian setiap warga selaku rakyat Indonesia masih beri kesempatan untuk memilik hak milik atas tanah.

5. Bumi, air dan ruang angkasa di seluruh wilayah Negara Kesatuan Republik Indonesia merupakan yang kemerdekaanya diperjuangkan Bangsa Indonesia sebagai keseluruhan menjadi hak Bangsa Indonesia, termasuk tanah-tanah di daerah-daerah dan pulau-pulau tidak semata-mata menjadi hak rakyat asli dari daerah atau pulau yang bersangkutan saja.

6. Mendasarkan pada rumusan bunyi pasal-pasal dan penjelasan tersebut, dikenal dengan sebutan asas kebangsaan. Kaidah-kaidah hukum yang menetapkan dan mengatur perihal kepemilikan hak milik atas tanah relatif cukup tepat, dikarenakan hak milik atas tanah merupakan suatu hak turun temurun yang terkuat dan terpenuh, di antara hak-hak atas tanah.

7. Asas kebangsaan dalam UUPA masih memiliki keterkaitan dan keterikatannya dengan Proklamasi Kemerdekaan Bangsa Indonesia, Pembukaan UUD Negara Republik Indonesia dan Dasar dan Tujuan Negara Kesatuan Republik Indonesia.

8. Asas kerohanian, hukum agraria nasional harus mewujudkan penjelmaan dari pada azas kerokhanian, Negara dan cita-cita Bangsa, yaitu Ketuhanan Yang Maha Esa, Perikemanusiaan, Kebangsaan, Kerakyatan dan Keadilan Sosial serta khususnya harus merupakan pelaksanaan dari pada ketentuan dalam pasal 


\section{AL-QISTH LAW REVIEW \\ VOL 5 NO. 1 (2021)}

33 Undang-undang Dasar dan Garis-garis besar dari pada haluan Negara.

9. Tanah-tanah di seluruh wilayah Negara Kesatuan Republik Indonesia diusahakan dan dikelola serta dimanfaatkan untuk mewujudkan kesejahteraan bagi keluarganya, yang merupakan bagian tidak terpisahkan dan tidak dapat dipisahkan dengan tujuan mewujudkan keadilan sosial bagi seluruh rakyat Indonesia.

Asas kerokhanian, merupakan suatu asas yang berkaitan dengan rokhani atau kebatinan. Asas ini memiliki keterikatan dengan pernyataan bangsa Indonesia yang dimuat dalam :

1. Alinea III Pembukaan UUD NRI Tahun 1945 menyatakan Atas berkat rakhmat Allah Yang Maha Kuasa dan dengan didorongkan oleh keinginan luhur, supaya berkehidupan kebangsaan yang bebas, maka rakyat Indonesia menyatakan dengan ini kemerdekaannya.

2. Aline IV Pembukaan UUD NRI Tahun 1945 menyatakan, ......yang terbentuk dalam suatu susunan Negara Republik Indonesia yang berkedaulatan rakyat dengan berdasar kepada : Ketuhanan Yang Maha Esa, Kemanusiaan yang adil dan beradab, Persatuan Indonesia, dan Kerakyatan jang dipimpin oleh hikmat kebijaksanaan dalam permusyawaratan/perwakilan, serta dengan mewujudkan suatu Keadilan sosial bagi seluruh rakyat Indonesia. 


\section{AL-QISTH LAW REVIEW \\ VOL 5 NO. 1 (2021)}

Dianut dan diterapkannya asas kerokhanian dalam UUPA menurut penulis sudah sangat tepat, mengingat yang berjuang dan telah berhasil mengusir penjajah dari bumi Indonesia, sehingga diperoleh kemerdekaan Bangsa Indonesia adalah bangsa Indonesia. Sebagaimana ternyata dari Proklamasi Kemerdekaan yang diucapkan oleh dwi tunggal Bangsa Indonesia Soekarno dan Hatta, pada tanggal 17 Agustus 1945, sebagai berikut: "Kami bangsa Indonesia dengan ini menyatakan Kemerdekaan Indonesia. Hal-hal yang mengenai pemindahan kekuasaan dan lain-lain. diselenggarakan dengan seksama dan dalam tempo sesingkat-singkatnya".

Istilah bangsa diartikan dengan: (1) Kesatuan orang-orang yang bersamaan asal keturunan, adat, bahasa, dan sejarahnya serta berperintahan sendiri; (2) Golongan mansuia, binatang, atau tumbuhtumbuhan yang mempunyai asal usul sama dan sifat khas yang sama atau bersamaan; (3) Macam, jenis; (4) Kedudukan (keturunan) mulia (luhur); (5) Janin kelamin; (6) Kumpulan manusia yang biasanya terikat karena kesatuan bahasa dan kebudayaan dalam arti umum dan yang biasanya mempunyai wilayah tertentu di muka bumi; (7) Klasifikasi di Biologi sesudah kelas dan sebelum ordo (Depdikbud, 1995).

Tampak jelas dalam rumusan arti bangsa dalam Kamus Besar Bahasa Indonesia, dimaksudkan sebagai kesatuan orang-orang dalam suatu wilayah dikenal dengan sebutan rakyat atau warga dari suatu pemerintahan baik yang berdasarkan agama seperti Vatikan maupun yang berdasarkan hukum, demokrasi dan sebagainya. Termasuk juga dengan 


\section{AL-QISTH LAW REVIEW \\ VOL 5 NO. 1 (2021)}

Negara Indonesia, maka warganya disebut dengan bangsa Indonesia yang di dalam melakukan perjuangan untuk memerdekakan bangsanya selalu didasarkan dan tidak dapat terpisahkan dan dipisahkan dengan ajaran kerokhaniannya, sehingga sampai diperoleh kemerdekaannya dan di dalam mengisi kemerdekaannya juga selalu dan tidak dapat tepisah dan dipisahkan dengan dasar kerokhaniannya.

Sebagaimana diketahui manusia sebagai mahkluk yang paling sempurna di antara makhluk-makhluk ciptaan Allah Swt lainnya. Hal demikian disebabkan manusia diciptakan terdiri atas unsur-unsur, raga atau badan, jiwa dan Rokh. Sedangkan makhluk-makhluk ciptaan lainnya, diciptakan tidak beraga, beraga dan berjiwa tetapi tidak memilik akal, hanya berlandaskan pada insting yang dimilikinya. Supaya manusia mampu memahami dan melaksanakan kewajiban-kewajiban yang dibebankan pada dirinya sebagai makhluk pengabdi Allah Swt selaku penciptanya selama menjalankan hidup dan kehidupan di muka Bumi. Apabila manusia telah menjalankan kewajiban-kewajibannya, Allah Swt akan memberikan haknya. Rokh urusan Allah Swt selaku Penciptanya.

Selain itu kepemilik hak milik atas tanah secara pribadi atau perorangan, diakui juga dalam Islam sebagai yang diterangkan dalam firman Allah SWT dalam surah Al Baqarah (Q.S. II : 188): "Dan janganlah sebagian kamu memakan harta sebagian yang lain di antara kamu dengan jalan yang batil dan (janganlah) kamu membawa (urusan) harta itu kepada hakim, 


\section{AL-QISTH LAW REVIEW \\ VOL 5 NO. 1 (2021)}

supaya kamu dapat memakan sebagian dari pada harta benda orang lain itu dengan (jalan berbuat) dosa, pada hal kamu mengetahui".

Berikutnya hadits Sa'id bin Zaid bahwsanya Rasulullah SAW telah bersabda barang siapa mengmbil sejengkal dari bumi dg kezhaliman, niscaya Allah kalungkan dia dengnya (dengan bumi yg ia ambil) pada hari Qiyamat dari 7 bumi (yakni dipaksa dia membawa bumi yg ia ambil itu dari sejauh tujuh bumi kepadang Mahsyar). Sedangkan asas kebangsaan, merupakan suatu asas yang berkaitan dengan perjuangan memerdekakan bangsa Indonesia dari seluruh penjajah. Asas ini memiliki keterikatan dengan penyataan bangsa Indonesia, sebagai berikut:

1. Proklamasi Kemerdekaan yang diucapkan oleh dwi tunggal Bangsa Indonesia Soekarno dan Hatta, pada tanggal 17 Agustus 1945, sebagai berikut: "Kami bangsa Indonesia dengan ini menyatakan Kemerdekaan Indonesia. Hal-hal yang mengenai pemindahan kekuasaan dan lain-lain diselenggarakan dengan seksama dan dalam tempo sesingkat-singkatnya";

2. Alinea I Pembukaan UUD NRI Tahun 1945: "bahwa sesungguhnya kemerdekaan itu ialah hak segala bangsa dan oleh sebab itu, maka penjajahan di atas dunia harus dihapuskan, karena tidak sesuai dengan peri-kemanusiaan dan peri-keadilan";

3. Alinea II Pembukaan UUD NRI Tahun 1945: “dan perjuangan pergerakan kemerdekaan Indonesia telah sampailah kepada saat yang berbahagia dengan selamat sentausa mengantarkan rakyat Indonesia ke 


\section{AL-QISTH LAW REVIEW \\ VOL 5 NO. 1 (2021)}

depan pintu gerbang kemerdekaan Negara Indonesia, yang merdeka, bersatu, berdaulat, adil dan makmur.

Kemudian daripada itu untuk membentuk suatu Pemerintah Negara Indonesia yang melindungi segenap bangsa Indonesia dan seluruh tumpah darah Indonesia dan untuk memajukan kesejahteraan umum, mencerdaskan kehidupan bangsa, dan ikut melaksanakan ketertiban dunia yang berdasarkan kemerdekaan, perdamaian abadi dan keadilan sosial, maka disusunlah Kemerdekaan Kebangsaan Indonesia itu dalam suatu Undang-undang Dasar Negara Indonesia, yang terbentuk dalam suatu susunan Negara Republik Indonesia yang berkedaulatan rakyat dengan berdasar kepada: Ketuhanan Yang Maha Esa, Kemanusiaan yang adil dan beradab, Persatuan Indonesia, dan Kerakyatan jangan dipimpin oleh hikmat kebijaksanaan dalam permusyawaratan/perwakilan, serta dengan mewujudkan suatu Keadilan sosial bagi seluruh rakyat Indonesia".

Di dalam hukum digunakan istilah orang ditempatkan dalam kedudukan selaku subyek hukum pemilik hak dan dibebani dengan kewajiban. Subyek hukum diartikan oleh para penulis, sebagai berikut:

1. Subyek hukum adalah "pemegang atau pengemban hak-hak dan kewajiban-kewajiban" (Kusumuaatmadja, 2009);

2. Penulis lain mengemukakan pendapatnya tentang rumusan subyek hukum dalam 3 (tiga) macam rumusan sebagai berikut :

1) Subyek Hukum adalah sesuatu yang menurut Hukum berhak/berwenang untuk melakukan Perbuatan Hukum atau 


\section{AL-QISTH LAW REVIEW \\ VOL 5 NO. 1 (2021)}

siapa yang mempunyai hak dan cakap untuk bertindak dalam Hukum.

2) Subyek Hukum adalah sesuatu pendukung hak yang menurut Hukum berwenang/berkuasa bertindak menjadi pendukung hak (Rechtsbevoegdheid).

3) Subyek Hukum adalah segala sesuatu yang menurut Hukum mempunyai hak dan kewajiban" (Soerso, 2011).

3. Subyek hukum dirumusan dengan arti segala sesuatu yang dapat memperoleh hak dan kewajiban dari hukum (Mertokusumo, 2002).

4. Subyek hukum adalah tiap-tiap pendukung hak dan kewajiban dalam lalu lintas hukum" (Ichsan, 1969).

5. Subyek hukum adalah pembawa hak dan dapat dilimpahkan kewajiban-kewajiban" (Kartohadiprodjo, 1981).

6. Subyek hukum adalah "pemangku hak dan kewajiban" (Hamzah, 1986).

7. Subyek hukum adalah "setiap makhluk yang berwenang untuk memiliki, memperoleh dan menggunakan hak serta kewajiban dalam lalu lintas hukum" (Marbun, 2012).

8. Subjek hukum "pendukung hak-hak dan dibebani dengan kewajiban-kewajiban" (Rido, 1977).

Selaku subyek hukum orang dapat memiliki hak milik bendabenda yang boleh dimiliki oleh subyek hukum, termasuk dengan tanah yang dikatagorikan ke dalam benda tidak bergerak. Sehingga di dalam 


\section{AL-QISTH LAW REVIEW \\ VOL 5 NO. 1 (2021)}

kaidah-kaidah hukum yang ditetapkan Pasal 21 UUPA, hanya Warganegara Indonesia yang dapat memiliki hak milik atas tanah.

Meskipun begitu di dalam pemilikan hak milik atas tanah undangundang, juga telah menetapkan dengan memberi wewenang kepada Pemerintah berupa amanat untuk menetapkan badan-badan hukum yang dianggap perlu diberi kepemilikan hak milik atas tanah. Kewenangan dimaksud didasarkan pada hak menguasai Negara atas tanah yang dimiliki oleh Pemerintah selaku penyelenggara dan pengelolan Negara.

Hak menguasai Negara kaidah-kaidah hukumnya ditetapkan dan dimuat dalam Pasal 2 UUPA, menentukan:

(1) Atas dasar ketentuan dalam pasal 33 ayat (3) Undang-undang Dasar dan hal-hal sebagai yang dimaksud dalam pasal 1, bumi, air dan ruang angkasa, termasuk kekayaan alam yang terkandung didalamnya itu pada tingkatan tertinggi dikuasai oleh Negara, sebagai organisasi kekuasaan seluruh rakyat.

(2) Hak menguasai dari Negara termaksud dalam ayat (1) pasal ini memberi wewenang untuk:

a. mengatur dan menyelenggarakan peruntukan, penggunaan, persediaan dan pemeliharaan bumi, air dan ruang angkasa tersebut;

b. menentukan dan mengatur hubungan-hubungan hukum antara orang-orang dengan bumi, air dan ruang angkasa,

c. menentukan dan mengatur hubungan-hubungan hukum antara orang-orang dan perbuatan-perbuatan hukum yang mengenai bumi, air dan ruang angkasa. 


\section{AL-QISTH LAW REVIEW \\ VOL 5 NO. 1 (2021)}

(3) Wewenang yang bersumber pada hak menguasai dari Negara tersebut pada ayat (2) pasal ini digunakan untuk mencapai sebesar-besar kemakmuran rakyat, dalam arti kebahagiaan, kesejahteraan dan kemerdekaan dalam masyarakat dan Negara hukum Indonesia yang merdeka berdaulat, adil dan makmur.

(4) Hak menguasai dari Negara tersebut diatas pelaksanaannya dapat dikuasakan kepada daerah-daerah Swatantra dan masyarakat-masyarakat hukum adat, sekedar diperlukan dan tidak bertentangan dengan kepentingan nasional, menurut ketentuan-ketentuan Peraturan Pemerintah.

Tampak jelas dapat dibaca dan diketahui dalam kaidah-kaidah hukum yang ditetapkan dalam pasal di atas, hak menguasai Negara dimiliki oleh Pemerintah selaku penyelenggara dan pengelola Negara, bertindak sebagai penguasa tanah. Adalah lebih tepat jika Negara, sebagai organisasi kekuasaan dari seluruh rakyat (bangsa) bertindak selaku Badan Penguasa. Kewenangan Pemerintah yang bersumber dari hak menguasai Negara, mengatur dan menyelenggarakan peruntukan, penggunaan, persediaan dan pemeliharaan bumi, air dan ruang angkasa termasuk tanah diarahkan pada pencapaian tujuan untuk mencapai sebesar-besar kemakmuran rakyat dalam rangka masyarakat yang adil dan makmur. Oleh karenanya memiliki kewenangan dan kekuasaan untuk memilih dan menetapkan badan-badan hukum yang dapat memiliki hak milik atas tanah. 


\section{AL-QISTH LAW REVIEW \\ VOL 5 NO. 1 (2021)}

Kewenangan dan kekuasaan yang dimiliki oleh Pemerintah berdasarkan hak menguasai Negara tidak diberikan secara seluas-luasnya, melainkan secara terbatas. Sehingga tidak dapat digunakan secara sewenang-wenang menetapkan setiap badan hukum dapat memiliki hak milik atas tanah, sebagaimana yang ditetapkan dalam kaidah-kaidah hukum dimuat Pasal 49, menentukan :

(1) Hak milik tanah badan-badan keagamaan dan sosial sepanjang dipergunakan untuk usaha dalam bidang keagamaan dan sosial, diakui dan dilindungi. Badan-badan tersebut dijamin pula akan memperoleh tanah yang cukup untuk bangunan dan usahanya dalam bidang keagamaan dan sosial.

(2) Untuk keperluan peribadatan dan keperluan suci lainnya sebagai dimaksud dalam pasal 14 dapat diberikan tanah yang dikuasai langsung oleh Negara dengan hak pakai.

(3) Perwakafan tanah milik dilindungi dan diatur dengan Peraturan Pemerintah.

Kaidah-kaidah hukum yang ditetapkan dan dimuat dalam Pasal 49 UUPA merupakan bentuk kaidah-kaidah pengecualian terhadap prinsip-prinsip dasar larangan badan-badan hukum untuk memiliki hak milik atas tanah, yang ditetapkan oleh undang-undang. Oleh karena itu dengan adanya kaidah-kaidah hukum tersebut, badan-badan hukum tertentu berdasarkan kewenangan, kekuasaan dan melalui penetapan Pemerintah, dimungkinkan untuk mempunyai hak milik atas tanah. 


\section{AL-QISTH LAW REVIEW \\ VOL 5 NO. 1 (2021)}

Penetapan badan-badan hukum yang memiliki hak milik atas tanah tidak dilakukan secara sembarang, melainkan didasarkan pada :

1. Sesuai dengan tujuan UUPA sebagai hukum dalam bentuk tertulis, berupa undang-undang tentunya di dalam pembuatannya sudah dilandasi dengan Pancasila sebagai dasar Negara dan ditujukan untuk mencapai kemakmuran rakyat dan pencapaian keadilan sosial bagi seluruh rakyat Indonesia.

2. Mengingat akan keperluan masyarakat yang sangat erat hubungannya dengan paham keagamaan, sosial dan hubungan perekonomian. Untuk itu tidak seluruh badan hukum dapat memiliki hak milik atas tanah, melainkan terbatas hanya badanbadan hukum yang bergerak dalam lapangan sosial dan keagamaan ditunjuk dalam pasal 49 sebagai badan-badan yang dapat mempunyai hak milik atas tanah, tetapi sepanjang tanahnya diperlukan untuk usahanya dalam bidang sosial dan keagamaan itu. Dalam hal-hal yang tidak langsung berhubungan dengan bidang itu mereka dianggap sebagai badan hukum biasa.

3. Larangan terhadap badan-badan hukum untuk memiliki hak milik atas tanah didasarkan pada pertimbangan karena badan-badan hukum tidak perlu mempunyai hak milik atas tanah, akan tetapi cukup dengan hak-hak lainnya, asal saja ada jaminan-jaminan yang cukup bagi keperluan-keperluannya yang khusus (hak gunausaha, hak guna-bangunan, hak pakai menurut pasal 28, 35 dan 41). Dengan demikian maka dapat dicegah usaha-usaha yang 


\section{AL-QISTH LAW REVIEW}

VOL 5 NO. 1 (2021)

bermaksud menghindari ketentuan-ketentuan mengenai batas maksimum luas tanah yang dipunyai dengan hak milik (pasal 17).

4. Tampak jelas badan-badan hukum yang dapat memiliki hak milik atas tanah, merupakan badan-badan hukum yang di dalam pengelolaan dan pengurusannya tidak dilakukan untuk mencari dan memperoleh keuntungan belaka, melainkan untuk kepentingan bangsa Indonesia di dalam mewujudkan tujuannya mencapai masyarakat adil dan makmur di seluruh wilayah Negara Kesatuan Republik Indonesia.

\section{PENUTUP}

UUPA telah menetapkan kaidah-kaidah hukum yang dimuat dalam Pasal 21, menyatakan hanya Warganegara Indonesia saja yang dapat memiliki hak milik atas tanah, dengan tidak membedakan laki-laki maupun Wanita ditempatkan pada kedudukan yang sederajat. Selain itu tidak membedakan pula dari golongan penduduk mana. Meskipun demikian melalui kewenangan yang dimiliki oleh Pemerintah selaku pemilik hak mengusai Negara dapat menentukan badan-badan hukum tertentu yang berusaha dibidang sosial, keagamaan dan pendidikan dapat memiliki hak milik atas tanah. 


\section{AL-QISTH LAW REVIEW}

VOL 5 NO. 1 (2021)

\section{DAFTAR PUSTAKA}

Depdikbud (1995). Kamus Besar Bahasa Indonesia, Jakarta : Balai Pustaka.

Depdikbud (1995), Kamus Besar Bahasa Indonesia, Jakarta : Balai Pustaka.

Hamzah, A. (1986), Kamus Hukum, Jakarta : Ghalia Indonesia.

Ichsan, A. (1969), Hukum Perdata IA, Jakarta :Pembimbing Masa.

Indonesia. (2000). Ketetapan Majelis Permusyawaratan Rakyat Republik Indonesia Nomor III/MPR/2000 tentang Sumber Hukum Dan Tata Urutan Peraturan Perundang-undangan, Di akses dari https:/ /ngada.org/mpr3-2000.htm

Indonesia. (1997). Peraturan Pemerintah Republik Indonesia Nomor 24 Tahun 1997 tentang Pendaftaran Tanah, Di akses dari https://peraturan.bpk.go.id/Home/Details/56273/pp-no-24-tahun$\underline{1997}$

Kartohadiprodjo, S. (1981), Pengantar Tata Hukum Indonesia, Jakarta : Ghalia Indonesia. 


\section{AL-QISTH LAW REVIEW}

VOL 5 NO. 1 (2021)

Kusumuaatmadja, M. dan Sidharta, B.A. (2009), Pengantar Ilmu Hukum : Pengenalan Pertama Ruang Lingkup Berlakunya Ilmu Hukum Buku I, Bandung, Alumni, (cetakan Kedua).

Kartohadiprodjo, S. (1981). Pengantar Tata Hukum Indonesia, Jakarta : Ghalia Indonesia.

Meliala, D. S. (2012), Hukum Perdata Dalam Perspektif BW, Bandung : Nuansa Alia.

Muhammad, A. (2000), Hukum Perdata Indonesia, Bandung : Citra Aditya Bakti.

Marbun, R. dkk. (2012). Kamus Hukum Lengkap, Mencakup Istilah Hukum dan Perundang-undangan Terbaru, Jakarta : Visimedia.

Rido, A. (1997), Badan Hukum dan Kedudukan Badan Hukum Perseroan, Perkumpulan, Koperasih, Yayasan, Wakaf, Bandung : PT. Alumni.

Soerojo, W. (1995), Pengantar dan Asas-asas Hukum Adat, Jakarta : Gunung Agung.

Soeroso, R. (2011), Pengantar Ilmu Hukum, Jakarta, Sinar Grafika, (cetakan kedua belas). 


\section{3 \\ AL-QISTH LAW REVIEW \\ VOL 5 NO. 1 (2021)}

Simanjuntak, P.N.H (1999). Pokok-Pokok Hukum Perdata Indonesia, Jakarta, Djambatan.

Sudikno Mertokusumo (2002), Mengenal Hukum Suatu Pengantar, Yogyakarta : Liberty.

Thalin, H. S. (1987), Politik Hukum Baru Mengenai Kedudukan Dan Peranan Hukum Adat Dan Hukum Islam Dalam Pembinaan Hukum Nasional, Jakarta : Fakultas Hukum Univeritas Muhammadiyah Jakarta. 